\title{
A Soil Test for Aluminium Toxicity in Acidic Subsoils of Yellow Earths in Western Australia
}

\author{
S. J. Carr; G. S. P. Ritchie and W. M. Porter
}

\begin{abstract}
Many of the yellow earths in the Western Australian wheatbelt have naturally acidic subsoils which can reduce the yield of wheat grown on them. Current methods of assessing soil acidity cannot identify which soils have subsoil acidity severe enough to restrict wheat yields.

We conducted 53 field experiments at 34 sites in 5 regions over 3 years to determine the relationship between yield of wheat and several different indices for identifying subsoils with toxic concentrations of aluminium, Al. Initially, we identified that the concentration of aluminium, [Al], in the soil solution and in $1: 50.005 \mathrm{M} \mathrm{KCl}$ extracts of soil from the 15-25 cm layer was responsible for the majority of the decrease in wheat yield.

The concentration of $\mathrm{Al}$ in a $1: 50.005 \mathrm{M} \mathrm{KCl}$ extract in the $15-25 \mathrm{~cm}$ layer was well correlated with grain yield of wheat grown on yellow earth soils in the Merredin region, provided the soils had similar fertilizer treatments. The ratio [Al] : [Na] in a $1: 50.005 \mathrm{M}$ $\mathrm{KCl}$ extract was a better predictor than [Al] alone of grain yield of wheat grown on yellow earths in different regions and with different fertilizer practices.

The three seasons had little effect on the correlation between yield and different soil indices. The correlations determined were strongly affected by regional differences, which were probably due to differing water supply and availability. The choice of toxicity index depended on the uniformity of fertilizer management practices within a region and it appeared that both ionic strength and calcium were important mitigating factors.
\end{abstract}

\section{Introduction}

Subsoil acidity has been recognized as an important yield-limiting factor on a wide variety of soils throughout the world (Adams and Lund 1966; Doss and Lund 1975; Adams and Moore 1983; McKenzie and Nyborg 1984; Farina and Channon 1988). Subsoil acidity has decreased the yield of lucerne (Medicago sativa) grown on the yellow podzolic soils of the Yass valley in eastern Australia (Simpson et al. 1979) and wheat (Triticum aestivum), lucerne and rape (Brassica napus) grown on the granitic soils in the southern tablelands of New South Wales (Pinkerton and Simpson 1986).

In Western Australia, wheat yields on the yellow earth soils in the eastern wheatbelt can be severely restricted by subsoil acidity (Porter and Wilson 1984). There are approximately one million hectares of the yellow earth soils [Um 5.22 (Northcote 1979); Norpa series (Bettenay and Hingston 1961)] which represent $30 \%$ of the total land area in the region. However, the full extent of the problem is difficult to define because current methods of assessing 
soil acidity cannot identify which soils have acidic subsoils severe enough to restrict wheat yields. There has been considerable research investigating the effect of topsoil lime application on the yellow earth soils (W. M. Porter, unpubl. data). Responses are rarely observed because the acidic subsoils are not ameliorated by surface liming.

Soil acidity decreases crop growth in several ways but aluminium toxicity is usually the most common mechanism (Foy 1974; McLean 1976). Not all forms of soluble aluminium are toxic to plants. Current evidence suggests that the activities of $\mathrm{Al}^{3+}$ and/or Al-hydroxy species are the most toxic to plants (Ritchie 1989). Aluminium complexed with anions such as sulfate, fluoride and organic ligands does not appear to decrease plant growth (Cameron et al. 1986; Hue et al. 1986). In addition, cations such as calcium (Clarkson and Sanderson 1971; Rhue and Grogan 1977; Cameron et al. 1986; Alva et al. 1986a, and to a lesser extent magnesium (Rhue and Grogan 1977; Wheeler et al. 1989; Edmeades et al. 1990) have been shown to mitigate aluminium toxicity. Hence, the concentration of total soluble aluminium [Al] may not be suitable as a soil test, because it does not consider the activity and forms of soluble aluminium. Measurement of the toxic forms of aluminium and allowance for the mitigating effects of ionic strength and individual cations is relatively straightforward in nutrient solutions but very time-consuming in soils because extraction of the soil solution is not adaptable to routine use. In the yellow earth subsoils, there are very few organic ligands because most of the organic matter is in the topsoil. The concentration of inorganic ligands also tends to be low in these subsoils, and hence most of the aluminium in subsoils may be in the toxic forms, $\mathrm{Al}^{3+}$ and hydroxy-Al. Therefore, a simple measure of $\mathrm{Al}$ may be sufficient to identify which yellow earth soils will depress crop yields. However, simple measures of $\mathrm{pH}$ or $\mathrm{Al}$ in $1 \mathrm{M} \mathrm{KCl}$ and $0.01 \mathrm{M} \mathrm{CaCl}_{2}$ extracts in the surface and subsoils do not distinguish between yellow earths containing toxic and those with non-toxic concentrations of aluminium (W. M. Porter, pers. commun.). This may be because total [Al] is an over-simplification as a measure of the toxic form of aluminium in solution, or because the extracting solution does not extract $\mathrm{Al}$ in proportion to the activity of the toxic forms of $\mathrm{Al}$ in the soil solution. Concentrated extracting solutions are more likely to remove Al from exchange surface sites as well as soluble aluminium (Moore and Ritchie 1988; Whitten and Ritchie 1991).

The objective of our research was to establish a soil test suitable for routine use that can identify yellow earth subsoils that contain toxic amounts of aluminium. We investigated soil tests that included parameters designed to take into account the mitigating effects of calcium and magnesium and the effect of ionic strength on the activity of aluminium.

Initially, we identified the depth of subsoil that was responsible for most of the decrease in wheat yield and then conducted laboratory experiments to determine the most suitable soil:liquid ratio for extractions by salt solutions and to find a cation in the $\mathrm{KCl}$ extract that had a concentration that was correlated with the ionic strength of the soil solution.

\section{Materials and Methods}

Field Experiments

In 53 field experiments, the yield of four varieties of wheat (Triticum aestivum cv. Millewa, Gutha, Aroona and Wilgoyne) was measured at two growth stages (vegetative yield at anthesis 
and grain yield at maturity) at 34 sites in 5 different regions over 3 years (Fig. 1). Yield was correlated with indices designed to identify acidic subsoils (sampled from seven different depths). The soil tests varied according to their extraction technique (soil : liquid ratio), extracting solution (soil solution, $\mathrm{KCl}$ and $\mathrm{CaCl}_{2}$ ) and the ions used as an index of acidity problem.

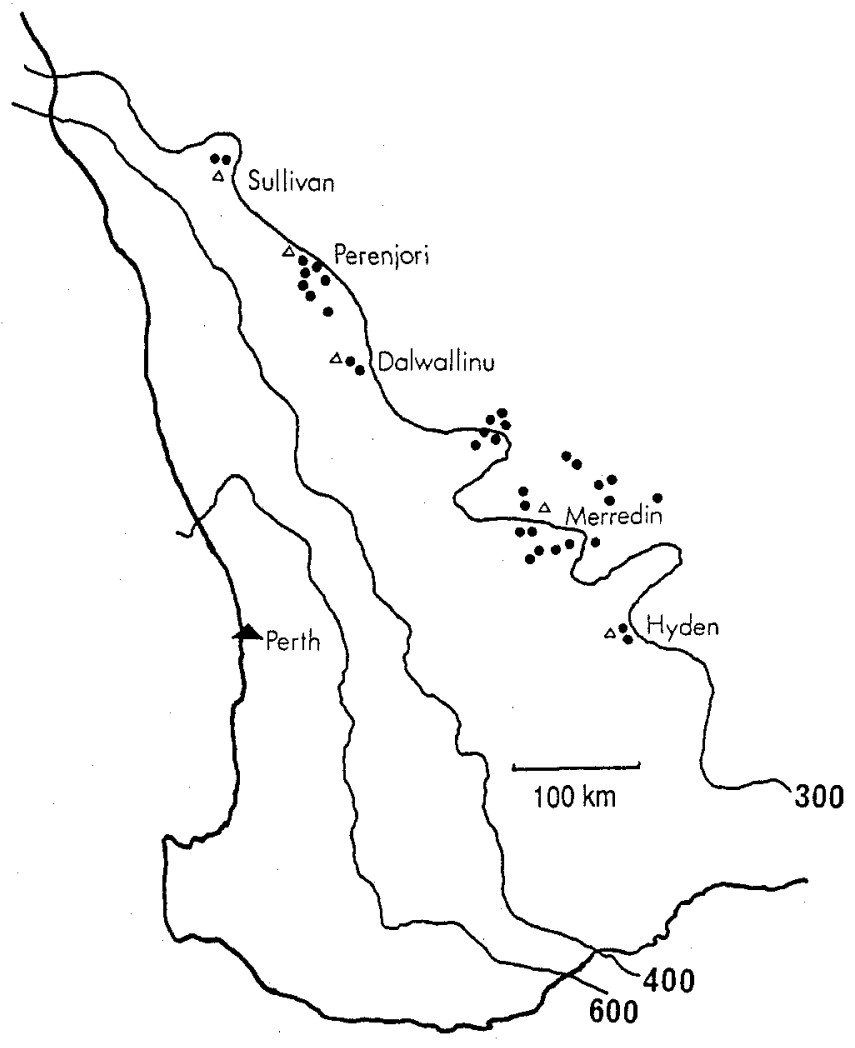

Fig. 1. Location of trial sites $(0)$ in the eastern wheatbelt of W.A. and rainfall isohytes (mm).

\section{Site and soil descriptions}

The Eastern wheatbelt of Western Australia has a Mediterranean climate. Average annual rainfall varies from region to region but is generally between 300 and $400 \mathrm{~mm}$ per annum with approximately $70 \%$ falling in the growing season (May-October). Some selected soil properties of the $0-10 \mathrm{~cm}$ layer are given in Table 1.

The initial 10 sites sown in 1987 were chosen from a comprehensive field survey of over 60 sites. A $3 \times 3$ or $4 \times 4$ grid sampling pattern was used. Duplicate soil cores to a depth of $2 \mathrm{~m}$ were taken at each grid point and the $\mathrm{pH}$ was determined at several depths within the soil profile. Experimental sites were chosen from sites that had the least variable $\mathrm{pH}$ at each depth. In the second and third years, site selection also included assessing $\mathrm{KCl}-[\mathrm{Al}]$.

\section{Experimental procedure}

In 1987 four varieties of wheat were grown in randomized block design at 10 sites located in the Merredin area $\left(31^{\circ} \mathrm{S}\right.$., $118^{\circ} \mathrm{E}$.), with from 4 to 12 replicates on $25 \times 1.4 \mathrm{~m}$ plots containing eight rows $0.18 \mathrm{~m}$ apart. Wheat was sown at $50 \mathrm{~kg} \mathrm{ha}^{-1}$. Trace element superphosphate was drilled with the seed at $363 \mathrm{~kg} \mathrm{ha}^{-1}\left(30 \mathrm{~kg} \mathrm{Pha}^{-1}, 2.2 \mathrm{~kg} \mathrm{Cu} \mathrm{ha}^{-1}\right.$, $1.1 \mathrm{~kg} \mathrm{Zn} \mathrm{ha}^{-1}$ and $220 \mathrm{~g} \mathrm{Mo} \mathrm{ha}^{-1}$ ). The sites were top-dressed with $\mathrm{NH}_{4} \mathrm{NO}_{3}$ at $270 \mathrm{~kg} \mathrm{ha}^{-1}$ 
(92 $\left.\mathrm{kg} \mathrm{N} \mathrm{ha}^{-1}\right)$. Fertilizer application rates were chosen to ensure nutrients did not limit plant growth based on previous experiments. Sprayseed ${ }^{2}$ herbicide $\left(2 \mathrm{~L} \mathrm{ha}^{-1}\right)$ was applied across all sites immediately before seeding. Post-emergent herbicides (Hoegrass $\$$ : diclofop-methyl and Brominil-M@: dicamba) were applied as required.

Table 1. Selected soil properties measured on $0-10 \mathrm{~cm}$ soil samples collected prior to seeding experiments

\begin{tabular}{|c|c|c|c|c|c|c|c|c|c|}
\hline \multirow{2}{*}{$\begin{array}{c}\text { First } \\
\text { year of } \\
\text { trial }\end{array}$} & \multirow[t]{2}{*}{ Region $^{A}$} & \multicolumn{8}{|c|}{ Soil property ${ }^{B}$} \\
\hline & & $\mathrm{p}$ & $\mathrm{K}$ & $\begin{array}{c}\mathrm{NO}_{3} \\
(\mathrm{ppm})\end{array}$ & $\mathrm{NH}_{4}$ & $\mathrm{Fe}$ & $\begin{array}{l}O C \\
(\%)\end{array}$ & $\begin{array}{c}E C \\
\left(d S m^{-1}\right)\end{array}$ & $\mathrm{pH}_{W}$ \\
\hline 87 & ME & 18 & 77 & 12 & 5 & 427 & 0.8 & 0.045 & $5 \cdot 8$ \\
\hline 87 & ME & 19 & 48 & 12 & 4 & 740 & $1 \cdot 2$ & 0.085 & $5 \cdot 4$ \\
\hline 87 & ME & 11 & 47 & 6 & 4 & 760 & 0.9 & 0.009 & $5 \cdot 2$ \\
\hline 87 & $\mathrm{ME}$ & 14 & 80 & 12 & 4 & 515 & $1 \cdot 0$ & 0.040 & $5 \cdot 6$ \\
\hline 87 & ME & 14 & 93 & 16 & 5 & 500 & $1 \cdot 0$ & 0.039 & $5 \cdot 4$ \\
\hline 87 & $\mathrm{ME}$ & 5 & 94 & 8 & 4 & 525 & 0.8 & 0.010 & $5 \cdot 8$ \\
\hline 87 & $\mathrm{ME}$ & 13 & 52 & 12 & 9 & 636 & $1 \cdot 0$ & 0.027 & $5 \cdot 1$ \\
\hline 87 & ME & 19 & 44 & 22 & 13 & 829 & 0.8 & 0.038 & $4 \cdot 7$ \\
\hline 87 & $\mathrm{ME}$ & 10 & 62 & 22 & 7 & 427 & 0.8 & 0.051 & $5 \cdot 4$ \\
\hline 87 & ME & 6 & 63 & 15 & 9 & 686 & 0.8 & 0.007 & $5 \cdot 6$ \\
\hline 88 & ME & 7 & 75 & 12 & 3 & 530 & 0.7 & 0.014 & $5 \cdot 2$ \\
\hline 88 & $\mathrm{ME}$ & 8 & 121 & 10 & 8 & 480 & 0.8 & 0.009 & $5 \cdot 6$ \\
\hline 88 & $\mathrm{ME}$ & 22 & 149 & 7 & 6 & 422 & 0.7 & 0.008 & $5 \cdot 6$ \\
\hline 88 & $\mathrm{ME}$ & 11 & 84 & 6 & 7 & 631 & 0.9 & 0.031 & $5 \cdot 1$ \\
\hline 88 & $\mathrm{ME}$ & 14 & 118 & 7 & 7 & 590 & 0.9 & 0.094 & $5 \cdot 0$ \\
\hline 88 & $\mathrm{ME}$ & 20 & 65 & 12 & 5 & 472 & 0.9 & 0.019 & $5 \cdot 2$ \\
\hline 88 & $\mathrm{ME}$ & 20 & 67 & 8 & 6 & 416 & 0.8 & 0.032 & $5 \cdot 4$ \\
\hline 88 & $\mathrm{ME}$ & 16 & 113 & 8 & 13 & 425 & 0.9 & 0.045 & $5 \cdot 6$ \\
\hline 88 & $\mathrm{ME}$ & 22 & 86 & 9 & 11 & 595 & $1 \cdot 3$ & 0.047 & $5 \cdot 3$ \\
\hline 88 & PL & 16 & 47 & 6 & 5 & 761 & 0.9 & 0.035 & $4 \cdot 9$ \\
\hline 88 & PL & 14 & 62 & 7 & 9 & 688 & 0.8 & 0.073 & $5 \cdot 2$ \\
\hline 88 & PL & 23 & 46 & 6 & 5 & 784 & $1 \cdot 1$ & 0.049 & $5 \cdot 5$ \\
\hline 89 & PL & 15 & 56 & 4 & 7 & 615 & 0.8 & 0.035 & $5 \cdot 2$ \\
\hline 88 & PL & 17 & 61 & 5 & 7 & 561 & $1 \cdot 1$ & 0.037 & $5 \cdot 2$ \\
\hline 88 & $\mathrm{PL}$ & 32 & 145 & 3 & 12 & 559 & 0.8 & 0.074 & $5 \cdot 2$ \\
\hline 89 & DA & 16 & 79 & 5 & 2 & 510 & 0.5 & 0.020 & $5 \cdot 6$ \\
\hline 89 & DA & 9 & 88 & 9 & 5 & 525 & $1 \cdot 1$ & 0.051 & $5 \cdot 2$ \\
\hline 89 & HY & 44 & 92 & 10 & 5 & 577 & $1 \cdot 2$ & 0.111 & $5 \cdot 0$ \\
\hline 89 & HY & 28 & 113 & 27 & 9 & 981 & $1 \cdot 0$ & 0.101 & $4 \cdot 9$ \\
\hline 89 & PL & 22 & 86 & 14 & 2 & 589 & 0.7 & 0.056 & $5 \cdot 0$ \\
\hline 89 & PL & 24 & 84 & 6 & 3 & 569 & 0.5 & 0.055 & $4 \cdot 9$ \\
\hline 89 & SU & 16 & 116 & 12 & 4 & 695 & 0.7 & 0.047 & $4 \cdot 9$ \\
\hline 89 & SU & 12 & 88 & 25 & 10 & 486 & 0.6 & 0.093 & $4 \cdot 9$ \\
\hline 89 & $\mathrm{ME}$ & 28 & 35 & 6 & 1 & 609 & 0.5 & 0.008 & $4 \cdot 7$ \\
\hline
\end{tabular}

A Region: ME, Merredin; PL, Perenjori/Latham; DA, Dalwallinu; HY, Hyden; SU, Sullivan.

${ }^{B} \mathrm{P}$ and $\mathrm{K}$ (Colwell 1963); $\mathrm{NO}_{3}$-specific ion electrode in $1: 5$ soil water extract; $\mathrm{NH}_{4}$-exchangeable in $1 \mathrm{M} \mathrm{KCl}$; Fe (Searle and Daly 1977); $\mathrm{OC}$ (Walkley and Black 1934); EC and $\mathrm{pH}_{\mathrm{W}}, 1: 5$ soil water extract.

In 1988, the ten original sites (first sown in 1987) and nine new sites also located in the Merredin area were sown in the same manner as 1987. Six similar experiments were sown in the Perenjori-Latham area $\left(29^{\circ} \mathrm{S} ., 116^{\circ}\right.$ E. $)$. Each experiment contained six replicates. All new experiments received the same basal fertilizer application as other sites received in 1987. All experiments that were resown in 1988 received plain superphosphate at $200 \mathrm{~kg} \mathrm{ha}^{-1}$ (18 $\mathrm{kg} \mathrm{Pha}^{-1}$ ) and $270 \mathrm{~kg} \mathrm{ha}^{-1}$ of $\mathrm{NH}_{4} \mathrm{NO}_{3}$. Herbicide application was the same as 1987 .

In the third and final year, five 1987 sites, eight 1988 sites and one new site all located in the Merredin area were sown in the same manner as 1988. Two new and three 1988 sites 
in the Perenjori-Latham area were resown in 1989. New experiments were sown at two sites each at Sullivan $\left(28^{\circ} \mathrm{S} ., 115^{\circ}\right.$ E.), Dalwallinu $\left(30^{\circ}\right.$ S., $116^{\circ}$ E.) and Hyden $\left(32^{\circ} \mathrm{S} ., 118^{\circ}\right.$ E. $)$. The new experiments received the same basal fertilizer application as the other sites received in 1987. The continuing experiments that were resown in 1989 received plain superphosphate at $200 \mathrm{~kg} \mathrm{ha}^{-1}$ and $270 \mathrm{~kg} \mathrm{ha}^{-1}$ of $\mathrm{NH}_{4} \mathrm{NO}_{3}$. Herbicide application was the same as 1987 .

The effect of topsoil lime application was also investigated in the Merredin area in 1988 and 1989. Six of the original sites were top-dressed with three rates of lime $(0,1$ and $3 \mathrm{tha}^{-1}$ ) (and cultivated with a scarifier to a depth of $10 \mathrm{~cm}$ prior to seeding in 1988); Gutha wheat was grown.

\section{Yield assessment}

Vegetative yield at anthesis was estimated by cutting the plants at ground level in four $0.5 \mathrm{~m}^{2}$ quadrats per plot. In 1987 the quadrats were bulked, oven-dried at $60^{\circ} \mathrm{C}$ and then weighed, while in 1988 the quadrats were bulked and weighed in the field immediately. A representative subsample was dried at $60^{\circ} \mathrm{C}$ and then weighed to calculate moisture content and hence dry matter production. Vegetative yield was not estimated in 1989 .

Grain yield was measured by harvesting the inside six rows with a small plot harvester (Wintersteiger Seedmaster or Hege-Model 125/C).

\section{Soil collection}

Prior to the beginning of the 1987 season, six cores $(75 \mathrm{~mm}$ diameter) were collected from each site (approximately 50 by $60 \mathrm{~m}$ ) and bulked into the specified depths of $0-5,5-10$, $10-15,15-25,25-50,50-75$ and $75-100 \mathrm{~cm}$. The samples were then frozen until laboratory analysis.

In 1988, three cores $(50 \mathrm{~mm}$ diameter) were collected from each half of the trial area (approximately 25 by $60 \mathrm{~m}$ ) and each set of three cores was bulked into the previously specified depths. In 1989, only 15-25 cm samples were collected from continuing experiments, while all depths were collected from the new sites by the same sampling strategy as used in 1988 . All samples collected in 1988 and 1989 were air-dried before storage.

Table 2. Summary of soil measurements

\begin{tabular}{cllc}
\hline Extract & \multicolumn{1}{c}{ Analyses } & Year & $\begin{array}{c}\text { Sample depth } \\
(\mathrm{cm})\end{array}$ \\
\hline Soil solution & $\mathrm{pH}, \mathrm{Al}, \mathrm{Ca}, \mathrm{Mg}, \mathrm{Na}, \mathrm{EC}$ & 1987 & All $^{\mathrm{A}}$ \\
Soil solution & $\mathrm{pH}, \mathrm{Al}, \mathrm{Ca}, \mathrm{Mg}, \mathrm{Na}, \mathrm{EC}$ & $1988 / 89$ & $15-25$ \\
$0.005 \mathrm{M} \mathrm{KCl}$ & $\mathrm{pH}, \mathrm{Al}, \mathrm{Ca}, \mathrm{Mg}, \mathrm{Na}$ & 1987,1989 & $15-25$ \\
$0.005 \mathrm{M} \mathrm{KCl}$ & $\mathrm{pH}, \mathrm{Al}, \mathrm{Ca}, \mathrm{Mg}, \mathrm{Na}$ & 1988 & All \\
\hline
\end{tabular}

A All depths $(0-5,5-10,10-15,15-25,25-50,50-75$ and $75-100 \mathrm{~cm})$.

\section{Soil analyses}

The soil analyses used in each year are summarized in Table 2.

Soil solution extraction and chemical analysis. The soil solution was extracted by adding deionized water to duplicate subsamples of each soil sample to raise the water content to $12 \%$ $\mathrm{w} / \mathrm{w}$ (approximately field capacity) and thoroughly mixing. The subsamples were incubated at $20 \pm 1^{\circ} \mathrm{C}$ for $16 \mathrm{~h}$ and then the soil solution was obtained by centrifugation (Gillman 1976). The filtered $(<0.45 \mu \mathrm{m})$ soil solution was analysed for aluminium by inductively coupled plasma atomic emission spectroscopy (ICPAES) in 1987 and colorimetrically using pyrocatechol violet (PCV) in 1988 and 1989 (Dougan and Wilson 1974). The pH was measured with an Orion EA 940 research pH meter, and calcium (Ca), magnesium (Mg), and sodium (Na) were measured by atomic absorption spectroscopy (AAS). In 1988 and 1989, potassium (K) was also measured by AAS, and electrical conductivity was measured by a conductivity meter.

$1: 5$ soil extracts. Duplicate subsamples of all $(1987,1988$ and 1989$)$ the $15-25 \mathrm{~cm}$ soll samples were shaken for $16 \mathrm{~h}$ with $0.005 \mathrm{M} \mathrm{KCl}$ at a soil : liquid ratio of $1: 5$ and then 
centrifuged. Another set of duplicate subsamples of the 15-25 cm layer of the soils collected from the 1988 sites was extracted with $0.01 \mathrm{M} \mathrm{CaCl}_{2}$. Duplicate subsamples of all other depths of the soils collected from the 1988 sites were shaken for 16 h with $0.005 \mathrm{M} \mathrm{KCl}$ at a soil : liquid ratio of $1: 5$ and then centrifuged. All filtered $(<0.45 \mu \mathrm{m})$ extracts were analysed for aluminium colorimetrically using PCV (Dougan and Wilson 1974). The pH was measured with an Orion EA 940 research $\mathrm{pH}$ meter, and $\mathrm{Ca}, \mathrm{Mg}$ and $\mathrm{Na}$ were measured by AAS in the $0.005 \mathrm{M} \mathrm{KCl}$ extracts.

\section{Data analysis}

Depth of Al toxicity. To identify the soil layer that was responsible for a major proportion of the low yields of wheat, we compared the correlation coefficient between yield and certain indices from each depth of soil that we sampled in the Merredin region in 1987 and 1988. In addition, we studied the response of wheat to lime in the $0-10 \mathrm{~cm}$ layer at three of the Merredin sites in 1988 and 1989.

Table 3. Soils tests evaluated in this study

\begin{tabular}{lll}
\hline $\begin{array}{l}\text { Toxicity } \\
\text { index }\end{array}$ & $\begin{array}{c}\text { Mitigating factor accounted for by } \\
\text { toxicity index }\end{array}$ & $\begin{array}{c}\text { Extraction } \\
\text { method }^{\mathrm{B}}\end{array}$ \\
\hline$[\mathrm{Al}]$ & none & $\mathrm{SS}, \mathrm{KCl}, \mathrm{CaCl}_{2}$ \\
{$[\mathrm{Al}] /[\mathrm{Ca}]$} & $\mathrm{Ca}$ & $\mathrm{SS}, \mathrm{KCl}$ \\
{$[\mathrm{Al}] /[\mathrm{Ca}+\mathrm{Mg}]$} & $\mathrm{Ca}, \mathrm{Mg}$ & $\mathrm{SS}, \mathrm{KCl}$ \\
{$[\mathrm{Al}] /[\mathrm{Ca}][\mathrm{Na}]$} & $\mathrm{Ca}$, ionic strength & $\mathrm{SS}, \mathrm{KCl}$ \\
{$[\mathrm{Al}] /[\mathrm{Na}]$} & ionic strength & $\mathrm{SS}, \mathrm{KCl}$ \\
{$[\mathrm{Al}] / \mathrm{EC}$} & ionic strength & $\mathrm{SS}$ \\
$(\mathrm{Al})$ & ionic strength & $\mathrm{SS}$ \\
$(\mathrm{Al}) / \mathrm{Ca})$ & $\mathrm{Ca}$, ionic strength & $\mathrm{SS}$ \\
$(\mathrm{Al}) /(\mathrm{Ca}+\mathrm{Mg})$ & $\mathrm{Ca}, \mathrm{Mg}$, ionic strength & $\mathrm{SS}$ \\
\hline
\end{tabular}

A [Al], concentration; (Al), activity.

${ }^{\text {B }} \mathrm{SS}$, soil solution; $\mathrm{KCl}, 0.005 \mathrm{M} \mathrm{KCl} ; \mathrm{CaCl}_{2}, 0 \cdot 01 \mathrm{M} \mathrm{CaCl}_{2}$.

Table 4. Grouping of data for correlation analysis

\begin{tabular}{|c|c|c|c|}
\hline $\begin{array}{l}\text { Group } \\
\text { code }\end{array}$ & $\begin{array}{l}\text { Data included in } \\
\text { group code }\end{array}$ & $\begin{array}{l}\text { No. of } \\
\text { trials }\end{array}$ & $\begin{array}{l}\text { Possible sources } \\
\text { of variation }\end{array}$ \\
\hline $87 \mathrm{M}$ & 1987 Merredin region & 9 & MF \\
\hline $88 \mathrm{M}$ & $\begin{array}{l}1988 \text { Merredin region (1st and } 2 \text { nd year of } \\
\text { experiment only) }\end{array}$ & 13 & MF, EA \\
\hline $\mathrm{MN}$ & First year only of each experiment, Merredin region & 19 & MF, S \\
\hline MA & $\begin{array}{l}\text { All years, Merredin region only (1st, } 2 \text { nd and } \\
\text { 3rd year of all experiments) }\end{array}$ & 36 & $\mathrm{MF}, \mathrm{EA}, \mathrm{S}$ \\
\hline AN & All years, all regions (1st year of experiment only) & 34 & $M F, R, S$ \\
\hline $\mathrm{AA}$ & $\begin{array}{l}\text { All years, all regions ( } 1 \text { st, } 2 \text { nd and } 3 \text { rd year } \\
\text { of all experiments) }\end{array}$ & 53 & MF, EA, R, S \\
\hline
\end{tabular}

$\bar{A} M F$, mitigating factors; $R$, regional differences; $E A$, experimental additions, i.e. fertilizer; $\mathrm{S}$, seasonal variation.

Development of a soil test. To ascertain the most appropriate soil test, two measures of plant growth (vegetative yield at anthesis and grain yield at maturity) were correlated with the soil tests described in Table 3 by nonlinear regression $\left(y=a x^{b}\right.$ and $y=10 \mathrm{e}^{b x}$ ). Relative yield was not used because there was no easy way of ameliorating Al toxicity in subsoils reliably.

The soil tests differed in their method of extraction and the chemical analysis of each extract (i.e. the toxicity index). The toxicity indices varied according to whether they accounted for mitigating factors such as $\mathrm{Ca}$ and $\mathrm{Mg}$ and/or ionic strength (as measured by cation summation in the soil solution, EC of the soil solution or [Na] in the soil solution of a $\mathrm{KCl}$ extract). 
The data were divided into a variety of different groups so that regional and seasonal effects on the correlations could be studied, as well as the possible effect of fertilizers added at each experimental site (Table 4).

Varietal response of wheat to Al toxicity in subsoils. Four cultivars of wheat were grown in all field experiments. These varieties were chosen using the haematoxylin staining technique (Polle et al. 1978) and from the observation that the range in tolerance exhibited by these varieties would be representative of all cultivars commonly grown on the soil type under study.

\section{Laboratory Experiments}

\section{Optimization of the soil : liquid ratio of $\mathrm{KCl}$ extracts}

We studied the effect of four soil-liquid ratios $(1: 1,1: 2,1: 5$ and $2: 1)$ on the correlation between the total aluminium in soil solution and the total $\mathrm{Al}$ extracted by $0.005 \mathrm{M} \mathrm{KCl}$ in the $15-25 \mathrm{~cm}$ layer of 20 of the soils, selected to cover the range of soil solution $\mathrm{Al}$ concentrations observed in all soils.

\section{Prediction of the soil solution ionic strength}

In order to estimate the ionic strength of the soil solution from a measurement made on a salt extract, we investigated the correlation between EC of the soil solution and the concentration of individual cations $(\mathrm{Ca}, \mathrm{Mg}, \mathrm{Na}$ and $\mathrm{K})$ in the soil solution and $\mathrm{KCl}$ extracts of the 15-25 cm layer of solls collected in 1988 and 1989.

\section{Results}

\section{Field Experiments}

\section{Variation in Al toxicity with depth}

The correlation between grain yield and possible indices of Al toxicity varied with depth for soils from the Merredin region (Table 5). The total

Table 5. Percentage of variation in grain yield explained by [Al] in soil solution (1987) and 1 : $50.005 \mathrm{M} \mathrm{KCl}$ extracts of soils (1988) from different depths of soil in the Merredin region

\begin{tabular}{cccccc}
\hline $\begin{array}{c}\text { Soil depth } \\
(\mathrm{cm})\end{array}$ & $\begin{array}{c}\text { Soil solution } \\
1987\end{array}$ & $\begin{array}{c}\mathrm{KCl} \\
1988\end{array}$ & $\begin{array}{c}\text { Soil depth } \\
(\mathrm{cm})\end{array}$ & $\begin{array}{c}\text { Soil solution } \\
1987\end{array}$ & $\begin{array}{c}\mathrm{KCl} \\
1988\end{array}$ \\
\hline $0-5$ & $\mathrm{NR}^{\mathrm{A}}$ & $\mathrm{NR}$ & $25-50$ & 85 & 71 \\
$5-10$ & $\mathrm{NR}$ & $\mathrm{NR}$ & $50-75$ & 67 & 66 \\
$10-15$ & 66 & 78 & $75-100$ & 83 & 63 \\
$15-25$ & 95 & 75 & & & \\
\hline
\end{tabular}

A NR, no relationship.
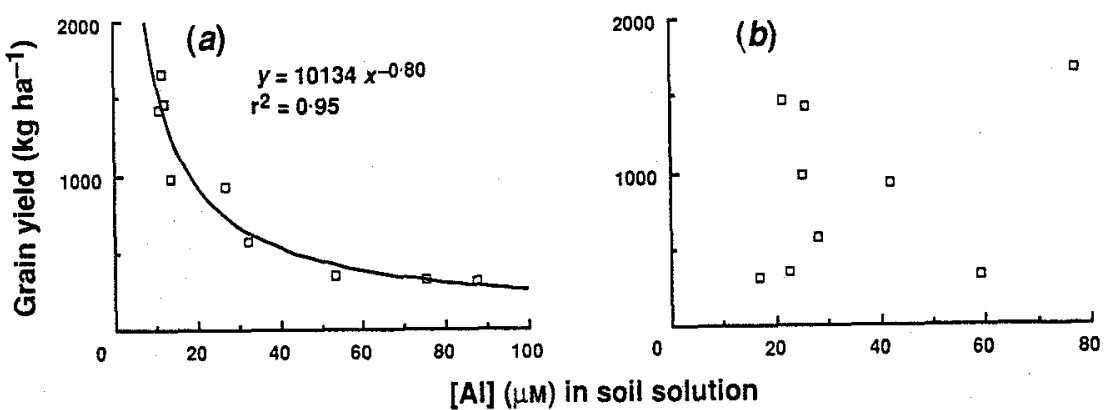

Fig. 2. Grain yield in 1987 plotted against the concentration of aluminium in the soil solution from $(a)$ the $15-25 \mathrm{~cm}$ layer and $(b)$ the $5-10 \mathrm{~cm}$ layer. 
concentration of aluminium in the soil solution from the $15-25 \mathrm{~cm}$ layer was most highly correlated with grain yield (Fig. $2 a$ ), whereas all measures of Al in the $0-5$ and $5-10 \mathrm{~cm}$ layers were poorly correlated Fig. $2 b$; Table 5 ). In contrast, $\mathrm{pH}$ in the $0-5 \mathrm{~cm}$ layer was well correlated with grain yield in 1987 (Fig. 3), but pH in any of the deeper soil layers was not correlated with yield. In 1987, the correlation between yield and [Al] in the soil solution of soil collected from depths greater than $25 \mathrm{~cm}$ was far better than those for the topsoil $(0-5$ and $5-10 \mathrm{~cm})$. The correlations for the deeper depths were more variable than the $15-25 \mathrm{~cm}$ layer (Table 5). The $15-25 \mathrm{~cm}$ layer was used in subsequent studies because the $10-15 \mathrm{~cm}$ layer represented a transition zone between soil horizons and hence could be more prone to natural variation.

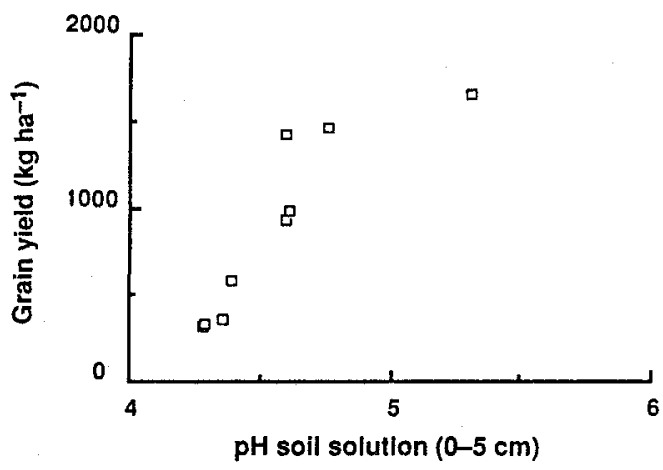

Fig. 3. Grain yield in 1987 plotted against the $\mathrm{pH}$ of the soil solution from the $0-5 \mathrm{~cm}$ layer.

Table 6. The effect of topsoil $(0-10 \mathrm{~cm})$ lime application on vegetative and grain yield ( $\left.\mathrm{kg} \mathrm{ha}^{-1}\right)$ of Gutha wheat in 1988 and 1989

(No significant differences for $P<0.05$ )

\begin{tabular}{ccccc}
\hline Site & $\begin{array}{c}\text { Lime rate } \\
\left(\mathrm{t} \mathrm{ha}^{-1}\right)\end{array}$ & $\begin{array}{c}\text { Vegetative } \\
1988\end{array}$ & $\begin{array}{c}\text { Grain } \\
1988\end{array}$ & $\begin{array}{c}\text { Grain } \\
1989\end{array}$ \\
\hline 1 & 0 & 706 & 172 & 132 \\
& 1 & 865 & 247 & 232 \\
& 3 & 931 & 253 & 245 \\
2 & 0 & 1623 & 547 & $\mathrm{NH}^{\mathrm{A}}$ \\
& 1 & 1488 & 585 & $\mathrm{NH}$ \\
& 3 & 1689 & 547 & $\mathrm{NH}$ \\
3 & 0 & 5454 & 1636 & 621 \\
& 1 & 5635 & 1745 & 621 \\
& 3 & 5253 & 1736 & 694 \\
\hline
\end{tabular}

A $\mathrm{NH}$, not harvested because of weed problems.

The application of lime to the $0-10 \mathrm{~cm}$ layer did not increase $(P<0.05)$ vegetative or grain yield during 1988 or 1989 (Table 6). Yields were only obtained from three of the six lime trials in 1988 and two sites in 1989 (due to weed problems at two sites and sheep damage at a third).

\section{Development of a soil test}

The correlation of vegetative or grain yield with soil tests for Al toxicity depended upon mitigating factors, seasonal and regional differences and 
fertilizer additions (Table 7). The ability of a soil test to predict yield was assessed by two criteria, namely the percent variation in yield explained by the soil test $\left(r^{2}\right)$ and the rate of change in the slope of the curve (i.e. $b$ in $\left.y=a x^{b}\right)$ : the less negative the value of $b$, the greater the drop in yield per unit change in the soil test and therefore the lower the accuracy of the soil test when predicting yield.

Table 7. Percentage variation in grain yield explained by soil test values (at $15-25 \mathrm{~cm}$ depth) when affected by seasonal and regional differences and fertilizer additions

Values in parentheses refer to negative $b$ coefficients from the nonlinear regression $y=a x^{b}$; asterisks indicate that the fitted curve is $y=10 \mathrm{e}^{b x}$

\begin{tabular}{|c|c|c|c|c|c|c|}
\hline \multirow[t]{3}{*}{ Index } & \multicolumn{4}{|c|}{ Merredin region } & \multicolumn{2}{|c|}{ All regions } \\
\hline & \multicolumn{2}{|c|}{ New trials } & \multicolumn{2}{|c|}{ All trials } & \multirow{2}{*}{$\begin{array}{c}\text { New trials } \\
87-89 \\
\text { (AN) }\end{array}$} & \multirow{2}{*}{$\begin{array}{c}\text { All trials } \\
87-89 \\
\text { (AA) }\end{array}$} \\
\hline & $\begin{array}{c}1987 \\
(87 M)^{A}\end{array}$ & $\begin{array}{c}87-89 \\
(\mathrm{MN})\end{array}$ & $\begin{array}{l}1988 \\
(88 \mathrm{M})\end{array}$ & $\begin{array}{c}87-89 \\
(\mathrm{MA})\end{array}$ & & \\
\hline \multicolumn{7}{|c|}{ Soil solution } \\
\hline [Al] & $\begin{array}{c}95 \\
(0.80)\end{array}$ & $\begin{array}{c}72^{*} \\
(0.0094)\end{array}$ & $\begin{array}{c}67^{*} \\
(0.0051)\end{array}$ & $\begin{array}{c}52 \\
(0-50)\end{array}$ & $\begin{array}{c}28^{*} \\
(0.0049)\end{array}$ & $\begin{array}{c}39^{*} \\
(0.0032)\end{array}$ \\
\hline (Al) & $\begin{array}{c}94 \\
(0 \cdot 83)\end{array}$ & $\begin{array}{c}69^{*} \\
(0.0139)\end{array}$ & $\begin{array}{c}76^{*} \\
(0.0113)\end{array}$ & $\begin{array}{c}53 \\
(0.52)\end{array}$ & $\begin{array}{c}42^{*} \\
(0.0119)\end{array}$ & $\begin{array}{c}46^{*} \\
(0.0077)\end{array}$ \\
\hline$[\mathrm{Al}] /[\mathrm{Ca}]$ & $\begin{array}{c}72 \\
(0 \cdot 64)\end{array}$ & $\begin{array}{r}61^{*} \\
(3.66)\end{array}$ & $\begin{array}{r}83^{*} \\
(2 \cdot 56)\end{array}$ & $\begin{array}{r}55^{*} \\
(2 \cdot 57)\end{array}$ & $\begin{array}{r}32^{*} \\
(2 \cdot 60)\end{array}$ & $\begin{array}{r}42^{*} \\
(2 \cdot 40)\end{array}$ \\
\hline$[\mathrm{Al}] /[\mathrm{Ca}][\mathrm{Na}]$ & $\begin{array}{c}54 \\
(0 \cdot 33)\end{array}$ & $\begin{array}{c}61 \\
(0 \cdot 19)\end{array}$ & $\begin{array}{c}73 \\
(0 \cdot 25)\end{array}$ & $\begin{array}{c}58 \\
(0 \cdot 24)\end{array}$ & $\begin{array}{c}44 \\
(0 \cdot 19)\end{array}$ & $\begin{array}{c}51 \\
(0 \cdot 24)\end{array}$ \\
\hline$[\mathrm{Al}] /[\mathrm{Na}]$ & $\begin{array}{c}71 \\
(0.41)\end{array}$ & $\begin{array}{c}65 \\
(0 \cdot 20)\end{array}$ & $\begin{array}{c}70 \\
(0 \cdot 26)\end{array}$ & $\begin{array}{c}62 \\
(0 \cdot 25)\end{array}$ & $\begin{array}{c}47 \\
(0 \cdot 21)\end{array}$ & $\begin{array}{c}56 \\
(0 \cdot 26)\end{array}$ \\
\hline \multicolumn{7}{|c|}{$1: 50.005 \mathrm{M} \mathrm{KCl}$ extract } \\
\hline [Al] & $\begin{array}{c}80 \\
(0 \cdot 56)\end{array}$ & $\begin{array}{c}74^{*} \\
(0.0116)\end{array}$ & $\begin{array}{c}75^{*} \\
(0.0087)\end{array}$ & $\begin{array}{c}60^{*} \\
(0.010)\end{array}$ & $\begin{array}{c}37^{*} \\
(0.0092)\end{array}$ & $\begin{array}{c}44^{*} \\
(0.0094)\end{array}$ \\
\hline$[\mathrm{Al}] /[\mathrm{Ca}]$ & $\begin{array}{c}73 \\
(0 \cdot 36)\end{array}$ & $\begin{array}{c}65 \\
(0.32)\end{array}$ & $\begin{array}{r}84^{*} \\
(0.61)\end{array}$ & $\begin{array}{r}60 \\
(0 \cdot 36)\end{array}$ & $\begin{array}{c}31 \\
(0 \cdot 25)\end{array}$ & $\begin{array}{r}39 \\
(0 \cdot 31)\end{array}$ \\
\hline$[\mathrm{Al}] /[\mathrm{Ca}][\mathrm{Na}]$ & $\begin{array}{c}62 \\
(0 \cdot 22)\end{array}$ & $\begin{array}{c}60 \\
(0 \cdot 17)\end{array}$ & $\begin{array}{r}71^{*} \\
(0 \cdot 54)\end{array}$ & $\begin{array}{r}64 \\
(0 \cdot 23)\end{array}$ & $\begin{array}{r}39 \\
(0 \cdot 16)\end{array}$ & $\begin{array}{c}53 \\
(0 \cdot 19)\end{array}$ \\
\hline$[\mathrm{Al}] /[\mathrm{Na}]$ & $\begin{array}{c}65 \\
(0 \cdot 30)\end{array}$ & $\begin{array}{c}53 \\
(0 \cdot 20)\end{array}$ & $\begin{array}{c}69^{*} \\
(0.0086)\end{array}$ & $\begin{array}{c}59 \\
(0.24)\end{array}$ & $\begin{array}{c}37 \\
(0 \cdot 20)\end{array}$ & $\begin{array}{c}52 \\
(0.24)\end{array}$ \\
\hline
\end{tabular}

A Labels in parentheses refer to group code in Table 4.

The highest correlation was found between grain yield and [Al] in the soil solution $\left(r^{2}=0.95, b\right.$ value $\left.=0.80\right)$ for data from one region (Merredin) in the same growing season (1987) with similar fertilizer additions (Group 87M in Table 7 ). The $b$ value of -0.80 also represents the most gradual decline in yield per given change in [Al], i.e. it is the most accurate soil test. The inclusion of mitigating factors in the soil test (by varying the toxicity index) did not improve the correlation. The concentration of $\mathrm{Al}$ in the $\mathrm{KCl}$ extract was also well correlated $\left(r^{2}=0.80, b\right.$ value $\left.=0.56\right)$ with grain yield for this group of trials. In contrast, the concentration of $\mathrm{Al}$ in a $\mathrm{CaCl}_{2}$ extract was not well correlated with grain yield $\left(r^{2}=0.58, b\right.$ value $\left.=-0.55\right)$.

The effect of seasonal variation on the ability of soil tests to predict grain yield was estimated from the trials included in Group MN of Table 7. Seasonal variation decreased the correlation coefficient (and increased the $b$ values) of grain yield and [Al] and the other toxicity indices in comparison with data 
from one season (Group 87M, Table 7), for example, [Al]/[Na] in soil solution $\left(r^{2}=0.71, b\right.$ value $=-0.41$ compared with $r^{2}=0.65, b$ value $\left.=-0.20\right)$. The decrease was not as marked in soil tests based on $\mathrm{KCl}$ extracts as for those extracting the soil solution. The inclusion of mitigating factors in an index (e.g. using (Al) rather than [Al]) did not increase the variation in grain yield explained by the soil tests.

The variation in fertilizer additions to trials in one region in the same year (i.e. Group $88 \mathrm{M}$ in Table 7) decreased the correlation between [Al] and (Al) (in both extracts) and grain yield. In contrast, all soil tests in Table 7 that accounted for mitigating factors improved upon the explained variation in grain yield (except $[\mathrm{Al}] /[\mathrm{Na}]$ in the soil solution where there was no change). However, the increase in $r^{2}$ was associated with an increase in the $b$ value, for example, $[\mathrm{Al}] /[\mathrm{Ca}][\mathrm{Na}]$ in soil solution $\left(r^{2}=0.54, b\right.$ value $=-0.33$ compared with $r^{2}=0.73, b$ value $=-0.25$ ).

The combined effect of seasonal variation and different fertilizer additions (Group MA in Table 7) markedly decreased the percentage of the variation in grain yield explained by all soil tests in comparison with that explained by soil tests for trials where no seasonal variation or different fertilizer regimes existed. In the soil solution, calcium had a minor effect on the explained variation, whereas the inclusion of sodium improved the correlation considerably ( $r^{2}$ from 0.52 to 0.62 ) but the $b$ value increased (from -0.5 to $-0 \cdot 25$, i.e. accuracy was decreased). For soil tests using $\mathrm{KCl}$ extracts, a combination of $\mathrm{Ca}$ and $\mathrm{Na}$ increased the correlation slightly but, individually, the inclusion of $\mathrm{Ca}$ or $\mathrm{Na}$ did not improve the explained variation. Comparison of the $b$ values was not possible because of the different models fitted to the data.

The correlations between grain yield and all the soil tests were low $\left(r^{2} \leq 0 \cdot 47\right)$ for trials from different regions in all three seasons but with similar fertilizer additions (Group AN in Table 7). The associated $b$ values for this group of trials were also low. However, indices that accounted for ionic strength were better correlated with grain yield than [AI].

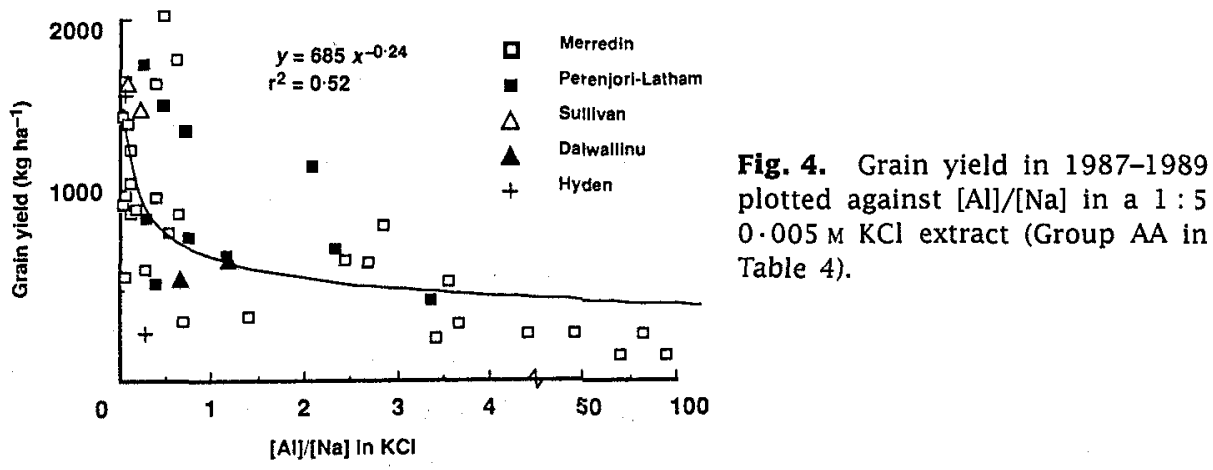

The percent variation in grain yield from all the trials (Group AA in Table 7) explained by [Al] in the soil solution and $\mathrm{KCl}$ extract was $39 \%$ and $44 \%$, respectively. The inclusion of measures of ionic strength in the toxicity index increased the percent variation in grain yield explained by the soil tests up 
to $56 \%$ and $52 \%$ respectively (Fig. 4). A comparison of the $b$ values for this increase in $r^{2}$ is not possible because of the different models fitted to the data. The inclusion of [Ca] in the toxicity index did not have a marked effect on the correlation (Table 7).

In general, correlation with grain yield was higher than with vegetative yield at anthesis in 1987 and 1988 (data not shown). Hence, vegetative yields were not measured in 1989.

Table 8. Changes in soil solution and $\mathrm{KCl}$ extractable [Al] and [Ca] (MM) in the $15-25 \mathrm{~cm}$ layer at five trial sites

\begin{tabular}{|c|c|c|c|c|c|c|c|c|c|}
\hline \multirow[t]{2}{*}{ Site } & \multicolumn{3}{|c|}{$[\mathrm{Al}]$} & \multicolumn{3}{|c|}{ [Ca] } & \multicolumn{3}{|c|}{$[\mathrm{All}] /[\mathrm{Ca}]$} \\
\hline & 1987 & 1988 & 1989 & 1987 & 1988 & 1989 & 1987 & 1988 & 1989 \\
\hline \multicolumn{10}{|c|}{ Soil solution } \\
\hline 1 & 88 & 125 & 390 & 362 & 354 & 952 & 0.24 & 0.35 & 0.41 \\
\hline 2 & 30 & 14 & 38 & 793 & 614 & 1081 & 0.04 & 0.02 & 0.04 \\
\hline 3 & 75 & 124 & 230 & 849 & 805 & 1600 & 0.09 & 0.15 & $0 \cdot 14$ \\
\hline 4 & 14 & 7 & 7 & 812 & 1103 & 500 & 0.02 & 0.01 & 0.01 \\
\hline 5 & 27 & 28 & 33 & 562 & 545 & 803 & 0.05 & 0.05 & 0.04 \\
\hline \multicolumn{10}{|c|}{ KCl extract } \\
\hline 1 & 68 & 77 & 96 & 35 & 53 & 26 & $1 \cdot 94$ & 1.45 & $3 \cdot 69$ \\
\hline 2 & 18 & 12 & 16 & 145 & 154 & 222 & 0.12 & 0.08 & 0.07 \\
\hline 3 & 47 & 67 & 44 & 44 & 108 & 174 & 1.07 & 0.62 & 0.25 \\
\hline 4 & 4 & 1 & 3 & 117 & 164 & 255 & 0.03 & 0.01 & 0.01 \\
\hline 5 & 16 & 23 & 15 & 103 & 120 & 165 & 0.16 & 0.19 & 0.09 \\
\hline
\end{tabular}

Seasonal changes in subsoil [Al] and [Ca]

The concentration of subsoil aluminium and calcium in the $15-25 \mathrm{~cm}$ layer changed through time (Table 8 ). There was a steady increase in the soil solution [Al] at sites 1 and 3 from 1987 to 1989, while there was little change at sites 2, 4 and 5. Similar trends were also observed in $\mathrm{KCl}$ extractable [Al], however, differences were far less pronounced. Soil solution [Ca] remained constant at four of the five sites between 1987 and 1988, but sharply increased between 1988 and 1989. In contrast, $\mathrm{KCl}$ extractable calcium steadily increased at four of the five sites from 1987 to 1988 and from 1988 to 1989.

The ratio $[\mathrm{Al}] /[\mathrm{Ca}]$ (in both soil solution and $\mathrm{KCl}$ extracts) increased at site 1 but remained relatively constant at the other four sites. An exception occurred at site 3 , where the ratio in the soil solution increased with time, whereas the ratio in $\mathrm{KCl}$ decreased.

Varietal response of wheat to Al toxicity in subsoils

Millewa (the most Al-tolerant wheat) generally yielded more than Gutha, which in turn yielded more than the most susceptible varieties Aroona and Wilgoyne (data not shown). Despite the difference in absolute yields between varieties, there was little difference in the correlation coefficients determined when the yield of individual varieties was correlated with the various soil tests (data not shown). The data presented are for the variety Gutha (the variety recommended by the Western Australian Department of Agriculture for the regions studied). 


\section{Laboratory Experiments}

Optimization of the soil : liquid ratio

The [Al] in soil solution was well correlated with [AI] in the $\mathrm{KCl}$ extracts at the soil : solution ratios studied $\left(r^{2}>0.85\right)$. The $a$ intercept ranged from $5 \cdot 35$ to $12 \cdot 22$ and the slope increased from 0.55 to 1.75 with increasing soil to solution ratio. None of the ratios examined was more highly correlated than the linear relationship between soil solution [Al] and [Al] in the more commonly measured 1:5 extract; hence, a ratio of $1: 5$ was used in all subsequent analyses.

\section{Prediction of soil solution ionic strength}

In 1988 and 1989, the EC of the soil solution was well correlated with an estimate of ionic strength (from the sum of the concentration of base cations $\mathrm{Ca}, \mathrm{Mg}, \mathrm{Na}$ and $\mathrm{K})$ in the soil solution $\left(r^{2}=0.84\right.$ and 0.88 respectively).

The estimated ionic strength calculated by the sum of the concentration of base cations was also well correlated with the ionic strength calculated from the EC of the soil solution by using the formula derived by Gillman and Bell (1978) for weathered tropical soils in north-eastern Australia $\left(r^{2}=0.85\right.$ and 0.63 in 1988 and 1989 respectively).

Table 9. Correlation coefficients for soil solution and $\mathrm{KCl}$ extractable cation concentrations and with soil solution electrical conductivity

\begin{tabular}{ccccc}
\hline$[\mathrm{KCl}]^{\mathrm{A}} v .[\mathrm{SS}]$ & 1987 & 1988 & 1989 & All years \\
\hline $\mathrm{Ca}$ & 0.19 & 0.22 & 0.28 & 0.13 \\
$\mathrm{Na}$ & 0.88 & 0.80 & 0.95 & 0.85 \\
$\mathrm{EC}$ of SS $v .[\mathrm{SS}]$ & & & & \\
$\mathrm{Ca}$ & 0.50 & 0.47 & 0.45 & 0.50 \\
$\mathrm{Na}$ & 0.80 & 0.78 & 0.75 & 0.56 \\
$\mathrm{EC}$ of SS $v .[\mathrm{KCl}]$ & & & & \\
$\mathrm{Ca}$ & 0.36 & 0.08 & 0.08 & 0.06 \\
$\mathrm{Na}$ & 0.67 & 0.51 & 0.72 & 0.56 \\
\hline
\end{tabular}

A $[X]$ refers to the concentration in $X$.

Soil solution [Na] was well correlated $\left(r^{2}>0 \cdot 75\right)$ and to a lesser extent $\mathrm{KCl}-[\mathrm{Na}]$ was correlated with the soil solution electrical conductivity (Table 9). The [Ca] in both soil solution and $\mathrm{KCl}$ extracts was not correlated with the soil solution electrical conducitivity. Therefore $[\mathrm{Na}]$ in $\mathrm{KCl}$ extracts was used as an estimate of ionic strength of the soil solution in some of the soil tests.

\section{Discussion}

The concentration of $\mathrm{Al}$ in the soil solution of the $15-25 \mathrm{~cm}$ layer predicted $>90 \%$ of the variation in grain yield of all the varieties of wheat in 1987 . The concentration of $\mathrm{Al}$ in a $1: 50.005 \mathrm{M} \mathrm{KCl}$ extract in the $15-25 \mathrm{~cm}$ layer was well correlated with grain yield of wheat grown on yellow earth soils in the Merredin region, provided that the soils had similar fertilizer treatments. The ratio $[\mathrm{Al}]:[\mathrm{Na}$ ] in a $1: 50.005 \mathrm{M} \mathrm{KCl}$ extract was a better predictor than [Al] alone of grain yield of wheat grown on yellow earths in different regions and with different fertilizer practices. 


\section{Development of Soil Tests}

\section{Regional and seasonal effects}

Regional differences caused a large drop in the performance of $\mathrm{KCl}$-[Al] as a predictor of grain yield. The $\mathrm{KCl}-[\mathrm{Al}]$ explained $74 \%$ of the variation in grain yield for trials in their first year in the Merredin region as opposed to $37 \%$ for all sites in their first year. The inclusion of a term in the toxicity index which accounted for the effects of ionic strength (i.e. activity or Na) improved correlations between yield and soil tests based on the soil solution but not for soil tests using $\mathrm{KCl}$ extracts (Group AN in Table 7). The combined effect of regional differences and fertilizer additions on the ability of a soil test to predict yield was improved by including $\mathrm{Na}$ in the soil test indices, whereas $\mathrm{Ca}$ was unable to improve on the explained variation between the Merredin region and all other regions.

The large difference in the explained variation in yield between the Merredin region and the other regions studied was also evident in the other soil tests examined (Table 7). This suggests that even though variation in ionic strength between regions may partly be mitigating $\mathrm{Al}$ toxicity, the major regional effect is probably due to environmental conditions such as water regime or anionic soil differences which were not measured.

Seasonal differences caused the least change in the correlation between grain yield and $\mathrm{KCl}$-[Al] with a region and for trial sites in their first year (Table 7). The incorporation of mitigating factors into the toxicity indices did not improve the correlation between seasons, suggesting that seasonal effects on the cation composition of the soil solution do not change the toxicity of $\mathrm{Al}$.

The effects of seasonal changes on the correlation between yield and soil tests using the soil solution were more marked than on soil tests based on $\mathrm{KCl}$ extracts. This indicated that even though $\mathrm{Al}$ measurements in $\mathrm{KCl}$ are well correlated with those in soil solution, some $\mathrm{Al}$ is being desorbed by the $\mathrm{KCl}$ from exchange sites. The combination of both sources of $\mathrm{Al}$ appears to be less sensitive to seasonal changes than soil solution $\mathrm{Al}$ alone. However, when $0.01 \mathrm{~m}$ $\mathrm{CaCl}_{2}$ was used as an extractant, far more $\mathrm{Al}$ was extracted from exchange sites and it was not correlated with $\mathrm{Al}$ in soil solution. In addition, the high $\mathrm{Ca}$ and ionic strength of the extract swamped the effects of the mitigating factors.

\section{Fertilizer additions}

The $\mathrm{KCl}$-[Al] explained less of the variation in grain yield when experiments involving different fertilizer inputs were compared. This was true, both within and between regions across all seasons. In general, the inclusion of mitigating factors into the soil index improved the level of explained variation, suggesting that fertilizers can affect Al toxicity by increasing the impact of mitigating factors such as ionic strength and calcium. The superiority of use of activities rather than concentrations to correct for differences in ionic strength was first shown by Adams and Lund (1966). Several researchers have subsequently noted improvement in the variation explained when ionic strength differences are accounted for (Blamey et al. 1983; Cameron et al. 1986; Bruce et al. 1988).

The role of calcium in mitigating the toxic nature of aluminium has been observed by several researchers (Clarkson and Sanderson 1971; Rhue and 
Grogan 1977; Alva et al. 1986a). Magnesium has also been considered to be able to decrease Al toxicity (Rhue and Grogan 1977; Wheeler et al. 1989; Edmeades et al. 1990), although this is less well supported than for calcium. In the soils we studied, inclusion of magnesium into the soil test indices (e.g. [Al]/[Ca+Mg]) failed to improve the explained variation compared with $[\mathrm{Al}] /[\mathrm{Ca}]$ alone. The lack of improvement in explained variation was noted for both soil solution and $\mathrm{KCl}$ extracts and could be due to (i) low concentrations of soil solution and $\mathrm{KCl}$ extractable magnesium, or (ii) a calcium deficiency in addition to aluminium toxicity.

Seasonal changes in subsoil [Al] and [Ca]. In the Merredin region, even though [Al] in $\mathrm{KCl}$ explained grain yield on sites varying in fertilizer additions quite adequately in 1987 and 1988 ( 0.80 and 0.75 respectively), there was a large drop in the correlation to 0.56 in 1989 . This drop coincided with a large change in the concentration of cations in the $15-25 \mathrm{~cm}$ layer of those soils which had been heavily fertilized for the previous 3 years. When [Al]/[Na] was used, correlations with grain yield were lower but did not change significantly between years $(0.62-0.64$ and $0.63-0.65$ respectively). This suggests that $\mathrm{KCl}-[\mathrm{Al}] /[\mathrm{Na}]$ may be a suitable soil test for subsoil Al toxicity on the yellow earths in the Merredin region as long as fertilizer strategies are similar. This would be a reasonable assumption in the context of current fertilizer practice. However, in a situation where lime and/or gypsum have been aplied, this may no longer be appropriate.

The increase in $\mathrm{Al}$ and $\mathrm{Ca}$ in the $15-25 \mathrm{~cm}$ layer from 1987 to 1989 was possibly due to the application of high rates of superphosphate applied to ensure phosphorus did not limit plant growth. The increase in soil solution [Al] and the progressive decline in the correlation coefficient for [Al] $v$. grain yield suggest that $\mathrm{Ca}$ from the gypsum component of superphosphate may have been displacing surface Al into solution (Horsnell 1985a, 1985b). The fact that the drop in $r^{2}$ was not completely removed by including mitigating factors in the toxicity index could indicate that the fertilizer may also have decreased $\mathrm{Al}$ toxicity by a mechanism not measured in our study. For example, sulfate and fluoride have both been shown to alleviate aluminium toxicity (Helyar 1978; Blamey et al. 1983; Cameron et al. 1986) and are both present in superphosphate.

The choice of best toxicity index depends on the uniformity of fertilizer management practices within a region and it appears that both ionic strength and calcium are important mitigating factors, but other factors not identified in this study (e.g. anion complexing) could be also important. If the ionic strength of the soil solution is to be altered by the application of lime or gypsum, then eventually [Na] in a $\mathrm{KCl}$ extract may not be well correlated with the ionic strength of the soil solution because $\mathrm{Ca}$ may become the dominant soluble cation.

\section{Sampling Depth}

The aluminium in the $15-25 \mathrm{~cm}$ layer was able to explain the majority of the variation in grain yield of wheat grown on the yellow earths. The high correlation between grain yield and $\mathrm{Al}$ in this layer indicated an important 
limitation to plant growth. A lack of root proliferation in this zone would prevent access to a substantial proportion of potentially available water. Roots affected by Al toxicity often have reduced lateral growth, which means they are inefficient in absorbing water and nutrients (Foy 1983; Scott and Fisher 1989). The lower variation in grain yield explained by [Al] from deeper in the soil profile is possibly due to the decrease in the crops requirement of water from deeper in the profile, or there are fewer roots deeper in the profile which are able to meet the water requirement.

Topsoil [Al] (measured in soil solution in 1987 and a $1: 50.005 \mathrm{M} \mathrm{KCl}$ extract in 1988) from the $0-5$ and $5-10 \mathrm{~cm}$ layers was not related to either grain or vegetative yield at all. The lack of correlation between topsoil solution $\mathrm{Al}$ and yield may be due to the formation of non-toxic Al-organic matter complexes (Bartlett and Riego 1972; Hoyt and Turner 1975; Hue et al. 1986). A large proportion of the soil organic matter occurs in the top $10 \mathrm{~cm}$ of these yellow earths. The likelihood of formation of non-toxic complexes in the soil below $15 \mathrm{~cm}$ is low. Although the $r^{2}$ value for the $10-15 \mathrm{~cm}$ soil layer in 1988 was slightly larger than that for the $15-25 \mathrm{~cm}$ layer $(0.78$ and 0.75 respectively), use of the $10-15 \mathrm{~cm}$ layer was rejected on a routine basis because it generally represents the region of transition from the topsoil to the subsoil, and its use for diagnosis of Al toxicity can be complicated by the presence of organic matter. Although the [Al] in extracts from soil below $25 \mathrm{~cm}$ was reasonably well correlated with yield, sampling at such depths would be more difficult as part of routine soil testing procedures.

In contrast, grain yield was well correlated with the $\mathrm{pH}$ of the soil solution from the $0-5 \mathrm{~cm}$ layer $\left(r^{2}>0.90\right)$ in 1987 , but not with $\mathrm{pH}$ from the other depths. The good correlation observed between 1987 topsoil solution $\mathrm{pH}$ and grain yield does not necessarily infer that liming the topsoil would increase grain yield on these soils. This was confirmed when the application of lime did not increase either vegetative or grain yield during 1988 or 1989 to an economically viable yield (Table 6). This provides further evidence that subsoil [Al] is the primary cause of yield loss on these soils. Porter and Wilson (unpubl. data) concluded that responses to liming the $0-10 \mathrm{~cm}$ layer of these soils are not common, and the responses that are observed are usually associated with overcoming a molybdenum deficiency and not a decrease in the toxicity of aluminium.

\section{Extraction Methodology}

Initially the plant growth correlations with indices calculated from the concentration and activities of $\mathrm{Al}, \mathrm{Ca}, \mathrm{Mg}, \mathrm{Na}$ and $\mathrm{EC}$ measured in the soil solution gave better relationships than salt extractions. However, this is a laborious procedure unsuited to routine use and was more prone to variation in seasonal and regional differences and fertilizer additions than $\mathrm{KCl}$ extracts.

The use of an extractant with the same ionic strength as the soil solution was considered to be least likely to disturb the equilibrium between soluble and solid phase $\mathrm{Al}$ in soil. Potassium chloride was chosen as an extractant because of the possible need to measure calcium due to its role in mitigating Al toxicity.

The Al extracted in $0.01 \mathrm{M} \mathrm{CaCl}_{2}$ has previously been used as a measure of Al toxicity (Bromfield et al. 1983). However, in our study, it was not well 
correlated with vegetative or grain yield nor was it correlated with soil solution Al. The $\mathrm{CaCl}_{2}$ extract has an ionic strength of 0.03 , which is considerably higher than the average 0.005 calculated for the highly weathered soils studied in our investigation. Presumably, the high concentration of $\mathrm{Ca}$ in the extract displaced Al from surface sites as well as soluble aluminium (Moore and Ritchie 1988; Whitten and Ritchie 1991).

The variation in grain yield of wheat explained by the various soil tests was always greater than the corresponding relationship for vegetative yield. A number of factors are likely to be responsible for this observation. Firstly, all correlations between yield and soil tests were determined using absolute yield. Hence, the large distances between experimental sites and the variation in sowing and sampling dates could mean that the environmental conditions during early vegetative growth may have affected yield just as much as any soil acidity restrictions. Secondly, the effects of Al on water availability or nitrogen uptake for post-anthesis grain fill may be more important than on pre-anthesis vegetative growth.

If a soil test is to be used across several regions in the south-west of Western Australia, then the current evidence suggests that $[\mathrm{Al}] /[\mathrm{Na}]$ would be the most consistent predictor of Al toxicity between seasons. The difference in correlation between grain yield and soil tests for a single region compared with all regions emphasizes the importance of variables not measured in the current study. The most likely causes of unexplained variation are differences in available water or nitrogen uptake, or an unidentified soil mitigating factor.

\section{Acknowledgments}

We wish to thank Messrs S. Cosh, G. Croker and W. Sharp for their assistance in maintaining the field experiments. The financial support of the Wheat Industry Research Committee of Western Australia is gratefully acknowledged.

\section{References}

Adams, F., and Lund, Z. F. (1966). Effect of chemical activity of soil solution aluminium on cotton root penetration of acid subsoils. Soil Sci. 101, 193-8.

Adams, F., and Moore, B. L. (1983). Chemical factors affecting root growth in subsoil horizons of coastal plain soils. Soil Sci. Soc. Am. J. 47, 99-102.

Alva, A. K., Asher, C. J., and Edwards, D. G. $(1986 a)$. The role of calcium in alleviating aluminium toxicity. Aust. J. Agric. Res. 37, 375-82.

Alva, A. K., Edwards, D. G., Asher, C. J., and Blamey, F. P. C. (1986b). Effects of phosphorus/aluminium molar ratios and calcium concentration on plant response to aluminium toxicity. Soil Sci. Soc. Am. J. 50, 133-7.

Bartlett, R. J., and Riego, D. C. (1972). Effect of chelation on the toxicity of aluminium. Plant Soil 37, 419-23.

Bettenay, E., and Hingston, F. J. (1961). The soils and land use of the Merredin area, Western Australia. CSIRO Aust. Soils Land Use Ser. No. 41.

Blamey, F. P. C., Edwards, D. G., and Asher, C. J. (1983). Effects of aluminium, $\mathrm{OH}: \mathrm{Al}$ and $\mathrm{P}$ : Al molar ratios, and ionic strength on soybean root elongation in solution culture. Soil Sci. 136, 197-207.

Bromfield, S. M., Cumming, R. W., David, D. J., and Williams, C. H. (1983). The assessment of available manganese and aluminium status in acid soils under subterranean clover pastures of various ages. Aust. J. Exp. Agric. Anim. Husb. 23, 192-200.

Bruce, R. C., Warrell, L. A., Edwards, D. G., and Bell, L. C. (1988). Effects of aluminium and calcium in the soil solution of acid soils on root elongation of Glycine Max cv. Forrest. Aust. J. Agric. Res. 38, 319-38. 
Cameron, R. S., Ritchie, G. S. P., and Robson, A. D. (1986). Relative toxicities of inorganic aluminium complexes to barley. Soil Sci. Soc. Am. J. 50, 1231-6.

Clarkson, D. T., and Sanderson, J. (1971). Inhibition of the uptake and long-distance transport of calcium by aluminium and other polyvalent cations. J. Exp. Bot. 22, 837-51.

Colwell, J. D. (1963). The estimation of phosphorus fertilizer requirements of wheat in southern New South Wales by soil analysis. Aust. J. Exp. Agric. Anim. Husb. 3, 190-7.

Doss, B. D., and Lund, Z. F. (1975). Subsoil pH effects on growth and yield of cotton. Agron. J. 67, 193-6.

Dougan, W. K., and Wilson, A. L. (1974). The absorptiometric determination of aluminium in water. A comparison of some chromogenic reagents and the development of an improved method. Analyst 99, 413-30.

Edmeades, D. C., Wheeler, D. M., Blamey, F. P. C., and Christie, R. A. (1990). The effects of calcium and magnesium on the amelioration of aluminium toxicity in Al-sensitive and Al-tolerant wheat. Proc. 2nd Int. Symp. on Plant-Soil Interactions at Low pH. 24-29 June 1990, Beckley, West Virginia.

Farina, M. P. W., and Channon, P. (1988). Acid-subsoil amelioration. I. A comparison of several mechanical procedures. Soil Sci. Soc. Am. J. 52, 169-74.

Foy, C. D. (1974). Effects of aluminium on plant growth. In 'The Plant Root and its Environment'. (Ed. E. W. Carson.) (Univ. Press of Virginia: Charlottesville, Va.)

Foy, C. D. (1983). The physiology of plant adaptation to mineral stress. Iowa State J. Res. 57, 355-91.

Gillman, G. P. (1976). A centrifuge method for obtaining soil solution. CSIRO Aust. Div. Soils Rep. No. 16.

Gillman, G. P., and Bell, L. C. (1978). Soil solution studies on weathered soils from tropical north Queensland. Aust. J. Soil Res. 16, 67-77.

Helyar, K. R. (1978). Effects of aluminium and manganese toxicities on legume growth. In 'Mineral Nutrition of Legumes in Tropical and Subtropical Soils. (Eds C. S. Andrew and E. J. Kamprath.) pp. 207-231. (CSIRO Aust.: Melbourne.)

Horsnell, L. J. $(1985 a)$. The growth of improved pastures on acid soils. I. The effect of superphosphate and lime on soil $\mathrm{pH}$ and on the establishment and growth of lucerne and phalaris. Aust. J. Exp. Agric. Anim. Husb. 25, 149-56.

Horsnell, L. J. (1985b). The growth of improved pastures on acid soils. II. The effect of lime and phosphorus and their incorporation in an acid soil on the growth of subterranean clover and lucerne pastures and on their response to superphosphate topdressing. Aust. J. Exp. Agric. Anim. Husb. 25, 157-63.

Hoyt, P. B., and Turner, R. C. (1975). Effects of organic materials added to very acid soils on $\mathrm{pH}$, aluminium, exchangeable $\mathrm{NH}_{4}$ and crop yields. Soil Sci. 119, 227-37.

Hue, N. V., Craddock, G. R., and Adams, F. (1986). Effect of organic acids on aluminum toxicity in subsoils. Soil Sci. Soc. Am. J. 50, 28-34.

McKenzie, R. C., and Nyborg, M. (1984). Influence of subsoil acidity on root development and crop growth in soils of Alberta and northeastern British Columbia. Can. J. Soil Sci. 64, 681-97.

McLean, E. O. (1976). Chemistry of soil aluminium. Commun. Soll Sci. Plant Anal. 7, 619-36.

Moore, C., and Ritchie, G. S. P. (1988). Aluminium speciation and pH of an acid soil in the presence of fluoride. $J$. Soil Sci. 39, 1-8.

Northcote, K. H. (1979). 'A Factual Key for the Recognition of Australian Soils.' (Rellim Technical Publications: Adelaide.)

Pinkerton, A., and Simpson, J. R. (1986). Responses of some crop plants to correction of subsoil acidity. Aust. J. Exp. Agric. 26, 107-13.

Polle, E. A., Konzak, A. F., and Kittirick, J. A. (1978). Visual detection of aluminum tolerance levels in wheat by haematoxylin staining of seedling roots. Crop Sci. 18, 823-7.

Porter, W. M., and Wilson, I. (1984). Soil acidity in the eastern wheatbelt. J. Agric. West. Aust. 25, 132-5.

Rhue, R. D., and Grogan, C. O. (1977). Screening corn for aluminium tolerance using different calcium and magnesium concentrations. Agron. J. 69, 755-60.

Ritchie, G. S. P. (1989). The chemical behaviour of aluminium, hydrogen and manganese in acid soils. In 'Soil Acidity and Plant Growth'. (Ed. A. D. Robson.) pp. 1-60. (Academic Press: Sydney.) 
Scott, B. J., and Fisher, J. A. (1989). Selection of genotypes tolerant of aluminium and manganese. In 'Soil Acidity and Plant Growth'. (Ed. A. D. Robson.) pp 167-204 (Academic Press: Sydney.)

Searle, P. L., and Daly, B. K. (1977). The determination of aluminium, iron, manganese and silicon in acid oxalate soil extracts by flame emission and atomic absorption spectrometry. Geoderma 19, 1-10.

Simpson, J. R., Pinkerton, A., and Lazdovskis, J. (1979). Interacting effects of subsoil acidity and water on the root behaviour and shoot growth of some genotypes of lucerne (Medicago sativa L.). Aust. J. Agric. Res. 30, 609-19.

Walkley, A., and Black. I. A. (1934). An examination of the Degtjareff method for determining soil organic matter, and a proposed modification of the chromic titration method. Soil Sci. 37, 29-38.

Wheeler, D. M., Blamey, F. P. C., Edmeades, D. C., and Christie, R. A. (1989). Effects of Ca and Mg on wheat. Proc. Aust. Acid Soil Res. Workshop, Coonawarra, S.A. Oct. 1989.

Whitten, M. G., and Ritchie, G. S. P. (1991). A comparison of soil tests to predict growth and nodulation of subterranean clover in acidic topsoils. Plant Soil (in press). 